\title{
A Recombinant Peptide, Hirudin, Potentiates the Inhibitory Effects of Stealthy Liposomal Vinblastine on the Growth and Metastasis of Melanoma
}

\author{
Rong-Rong Guo, Yang Liu, Wan-Liang Lu,* Ji-Hui Zhao, Xue-Qing Wang, Hua Zhang, \\ Jian-Cheng Wang, Xuan Zhang, and Qiang Zhang* \\ State Key Laboratory of Natural and Biomimetic Drugs and School of Pharmaceutical Sciences, Peking University; Beijing \\ 100083, China. Received October 24, 2007; accepted December 3, 2007; published online January 15, 2008
}

The metastasis of tumor cells is one of the major obstacles to successful clinical therapy. A treatment strategy by incorporating a specific inhibitor of thrombin, recombinant hirudin with stealthy liposomal vinblastine, was used in this study for inhibiting the metastasis of tumor cells and enhancing the efficacy of anti-tumor agents. In vitro cytotoxicity, cell adhesion to extracellular matrix (ECM) proteins, and cell invasion and migration assays were performed on human A375 melanoma cell line. In vivo measurement of coagulation parameters, inhibition of tumor growth, and inhibition of metastasis were assessed in female BALB/c mice. In vitro, vinblastine or stealthy liposomal vinblastine alone was effective to inhibit the growth of A375 cells. On the contrary, hirudin had no influence on either cytotoxicity when treating with hirudin alone or hirudin plus vinblastine. In addition, in vitro results showed that hirudin had no impact on the adhesion of tumor cells to extracellular matrix proteins, and metastasis and invasion of tumor cells. In mice, hirudin significantly inhibited the activity of thrombin. Furthermore, administered at the initial implantation of murine B16 melanoma cells, hirudin evidently delayed the growth of tumor, and depressed the occurrence of experimental lung metastasis. A subsequent administration of stealthy liposomal vinblastine resulted in further inhibiting growth and metastasis of tumor, indicating that hirudin plus stealthy liposomal vinblastine exhibited a significant anti-metastasis effect and slightly potent effect against tumor growth as compared with stealthy liposomal vinblastine alone. In conclusion, administration of recombinant hirudin followed by giving stealthy liposomal vinblastine may be beneficial for inhibiting the growth and metastasis of melanoma in vivo. The likely mechanism could be associated with inhibition of thrombin after administration of hirudin.

Key words metastasis; melanoma; recombinant hirudin; stealthy liposomal vinblastine; thrombin

The metastasis of tumor cells is one of the major obstacles to successful clinical chemotherapy, surgery, and radiotherapy. Accordingly, new therapeutic strategies are needed for overcoming the occurrence of invasion and metastasis of tumor to improve patients' prognosis and survival.

The anticoagulants low-molecular weight heparin (LMWH) and recombinant hirudin have shown anti-invasion and antimetastasis effects in experimental models. ${ }^{1,2)}$ However, recombinant hirudin was found ineffective at preventing metastasis of HT168-M1 human melanoma cells in preclinical study, ${ }^{1)}$ suggesting that the anti-invasion and anti-metastasis effects of anticoagulants may vary by tumor cells. Most likely, each anticoagulant agent has its own mechanisms for application.

The association of thrombosis and cancers as evidenced by platelet and fibrin deposition is well established. ${ }^{3-6)}$ Previous studies indicate that exogenous thrombin $(1 \mathrm{U} / \mathrm{ml})$ acting through its protease-activated receptor (PAR-1) is capable of enhancing tumor adhesion to platelets, ${ }^{7-9)}$ endothelial cells, ${ }^{10)}$ fibronectin, and von Willebrand factor ${ }^{8)}$ in vitro. Studies have also revealed that exogenous thrombin promotes tumor growth in vitro ${ }^{11)}$ and in vivo ${ }^{7,8,12)}$ as well as metastasis in experimental animals (via tail-vein injection of cancer cells). ${ }^{9,13)}$ The endogenous generation of host thrombin plays a significant role during tumor growth and spontaneous metastasis. ${ }^{2)}$ Recent investigation demonstrated that advanced cancer is associated with a hypercoagulable state triggered by tissue factor (TF) ${ }^{14)}$ TF-initiated thrombin generation is a critical step for metastasis through fibrin, platelet deposition, and PAR-1 signaling responses. In addition, PAR-
2, which was not cleaved by thrombin, appears to be a cosignal with PAR-1 to elicit thrombin effects in metastatic tumor cells. ${ }^{14)}$

Hirudin is a highly potent and specific inhibitor of thrombin. It has shown an inhibitory effects against tumor growth and metastasis in experimental tumor models. ${ }^{15-17)}$ Hirudin induced a pronounced lag time in the appearance of tumor growth, as compared with phosphate-buffered saline (PBS) as control, but had no effect on existing tumor cells. We postulated that hirudin may have different effects on tumor growth depending on its administrations, because hirudin resulted in central necrosis of the tumor nodule, and inhibited spontaneous metastases from subcutaneously implanted tumor by reducing the number of tumor nodules in the lungs following administration at early stage of tumor cell inoculation in experimental animals. ${ }^{2)}$

Heparins are negatively charged polysaccharides that are able to bind to a number of proteins and molecules, thus probably influencing their biological activity. LMWH is composed of low-molecular weight fragments of heparin manufactured by controlled enzymatic or chemical depolymerization. LMWH may affect the progression of tumor in many ways. For example, it may potentially inhibit intravascular arrest and metastasis due to its anticoagulant role. ${ }^{18-20)}$ In addition, it could affect proliferation and migration of cancer cells and angiogenesis in tumors by binding to growth factors and ECM proteins. ${ }^{21-23)}$ Furthermore, LMWH is capable of inhibiting expression of oncogenes and influencing the immune system in animals. ${ }^{24)}$

Malignant melanoma is one of the most potentially 
metastatic human cancers, where even a few millimeter-thick tumor may lead to a high risk for developing distant metastasis within 5 years. ${ }^{1)}$ Furthermore, this type of tumor is highly resistant to chemotherapy. The response rates of anticancer agents to this tumor are $<20 \%$. Therefore enhancing the efficiency of anticancer agents and preventing the occurrence of metastasis are challenging tasks for researchers in looking for a therapeutic strategy against malignant melanoma. In the present study, murine B16 melanoma cells were included for illustrating the mechanism and effect because these cells have thrombin receptors (PAR-1) expressed on the cell's surface, while recombinant hirudin is a specific inhibitor of thrombin.

Vinblastine is a broad-spectrum anticancer agent mainly used for the treatment of solid tumors. In our pre-experiment using tumor-bearing mice, administration of free vinblastine caused a high death incidence (at a rate of 4/6) most likely due to its acute exposure toxicity together with bone marrow depression or neurotoxicity of peripheral neuronal system. However, giving this agent as stealthy liposomal formulation at the same dose of free vinblastine did not kill the animals, indicating that liposomal encapsulation of vinblastine could alleviate acute systemic toxicity of this agent. The stealthy liposomes, which are modified with polyethylene glycoldistearoyl phosphophatidylethanolamine $\left(\mathrm{PEG}_{2000}-\mathrm{DSPE}\right)$ or other pegylated lipid derivatives, have a very long circulatory half-life by inhibiting rapid uptake by the reticuloendothelial system as compared with regular liposomes or un-encapsulated drug, ${ }^{25)}$ and are less toxic as compared with un-encapsulated drug (free drug). The stealthy liposomes accumulate more in tumors as a result of their ability to extravasate through 'pores' in the capillary endothelium, ${ }^{26,27)}$ leading to an enhanced activity. To date, the effect and mechanism on invasion, metastasis, and growth of melanoma when hirudin is co-treated with an anticancer agent have not been fully defined

The objectives of the present study were to illustrate the effect of treating with recombinant hirudin followed by treating with liposomal vinblastine on the in vitro and in vivo growth and metastasis of melanoma.

\section{MATERIALS AND METHODS}

Preparation of Stealthy Liposomal Vinblastine A transmembrane ionic gradient was used in the preparation of stealthy liposomal vinblastine to achieve high drug-loading efficiency as reported previously. ${ }^{28)}$ Briefly, egg phosphatidylcholine (EPC), cholesterol, and polyethylene glycoldistearoyl phosphophatidylethanolamine $\left(\mathrm{PEG}_{2000}-\mathrm{DSPE}\right.$, NOF Corporation, Japan) (55/40/5, molar ratio) were dissolved in chloroform. The chloroform was evaporated to produce a lipid film under vacuum, and the lipid film was subsequently hydrated with ammonium sulfate $(0.25 \mathrm{M}, \mathrm{pH} 5.1)$ by sonication in an ice water bath for $30 \mathrm{~min}$ to obtain the blank stealthy liposomes. The liposomes were successively extruded through polycarbonate membranes (Nuclepore, Germantown, MD, U.S.A.) with pore sizes $0.6,0.4$, and $0.2 \mu \mathrm{m}$ for 3 times each. The resulting liposomes were sealed in a dialysis tubing (MW cutoff $12000-14000 \mathrm{Da}$ ) and dialyzed in physiological saline for 4 times over $32 \mathrm{~h}$ to exchange the external phase. Vinblastine was remote-loaded via an ammo- nium sulfate gradient method.

The concentration of vinblastine was measured by highperformance liquid chromatography (HPLC). The determination conditions were as follows: mobile phase, a mixture solution consisting of a $1.5 \%(\mathrm{v} / \mathrm{v})$ solution of diethylamine adjusted to $\mathrm{pH} 7.5$ with phosphoric acid, acetonitrile, and methanol $(22: 18: 60, \mathrm{v} / \mathrm{v} / \mathrm{v})$; detection wavelength, $262 \mathrm{~nm}$; chromatogram column, an octadecyl $\left(\mathrm{C}_{18}\right), 5 \mu \mathrm{m}(200 \times 4.6$ $\mathrm{mm}$ i.d., Kromasil) column. Linearity was obtained for vinblastine concentrations between 0.5 and $50 \mu \mathrm{g} / \mathrm{ml}\left(r^{2}=\right.$ $0.9995)$. The coefficient of variation of the inter-day and intra-day precision of the quality-control samples was $<5 \%$ and recovery ranged from 96.5 to $102.2 \%$.

The in vitro vinblastine release from liposomes was measured by dialysis method. For encapsulation efficiency of vinblastine $>95 \%$, free vinblastine in liposomes was not removed. Dialysis was conducted in PBS ( $\mathrm{pH} 7.4$ ) or $50 \%$ fetal bovine serum (FBS) in PBS. Liposomes at a concentration of $1 \mathrm{mg}$ vinblastine per $\mathrm{ml}$ diluted in the media were enclosed in dialysis tubing (MW cutoff 12000-14000 Da) sealed at both ends with clips. The liposomes-loaded dialysis tubes were then placed into a beaker containing $50 \mathrm{ml}$ of PBS, and incubated at $37^{\circ} \mathrm{C}$ for $48 \mathrm{~h}$. At various time points, an aliquot of $2 \mathrm{ml}$ sample was withdrawn from the beaker and replaced with equal volume of PBS. The concentrations of vinblastine in samples were then measured, and the cumulative release rates were calculated.

Cell Culture Human A375 melanoma cell line (from the Basic-Medical Cell Center, Chinese Academy of Medical Science, Beijing, China) was maintained in vitro in Dulbecco's modified Eagle's medium (DMEM) supplemented with $10 \%$ fetal bovine serum (FBS, Hyclone, Thermo Fisher Scientific Inc., Whitehouse Station, NJ, U.S.A.) and 1\% penicillin-streptomycin solution $(5000 \mathrm{U} / \mathrm{ml}$ penicillin and 5 $\mathrm{mg} / \mathrm{ml}$ streptomycin) at $37^{\circ} \mathrm{C}$ in a $5 \% \mathrm{CO}_{2}$ atmosphere. Murine B16 melanoma cell line (from the Cell Bank of Chinese Academy of Science, Shanghai, China) was grown in RPMI-1640 medium plus $10 \%$ FBS and 1\% penicillin-streptomycin solution $(5000 \mathrm{U} / \mathrm{ml}$ penicillin and $5 \mathrm{mg} / \mathrm{ml}$ streptomycin) at $37^{\circ} \mathrm{C}$ in a $5 \% \mathrm{CO}_{2}$ atmosphere.

Cytotoxicity Assay The assay was performed using a quantitative determination of viable cells based on the conversion of the yellow tetrazolium salt, 3-(4,5-dimethylthiazol-2-yl)- 2,5-diphenyl tetrazolium bromide (MTT), to purple formazan crystals by metabolically active cells. ${ }^{29)}$ A375 cells were seeded in 96-well plates in DMEM containing $10 \%$ FBS at a density of 5000 per well. After incubation for $24 \mathrm{~h}$, cells were treated with various concentrations of hirudin, vinblastine, liposomal vinblastine, or LMWH (Sanofi Winthrop Industrie, GlaxoSmithKline, France) (200 $\mathrm{IU} / \mathrm{ml}$ ) at $37^{\circ} \mathrm{C}$ in a $5 \% \mathrm{CO}_{2}$ atmosphere. Cells incubated in medium without applying any drug were used as the controls. After incubation for $48 \mathrm{~h}, 20 \mu \mathrm{l} /$ well of MTT $(5 \mathrm{mg} / \mathrm{ml})$ was added and the plates were incubated for an additional $4 \mathrm{~h}$. The medium was removed and the purple formazan crystals were solubilized in $100 \mu \mathrm{l}$ of dimethylsulfoxide (DMSO) at room temperature for $10 \mathrm{~min}$. The absorbance value of each sample was measured on a microplate reader at $490 \mathrm{~nm}$.

Cell Adhesion to Extracellular Matrix (ECM) Proteins ECM proteins, including fibronectin, collagen I (from rat tail), fibrinogen (Fraction I, from human plasma), and ECM 
gel (all from Sigma), were diluted to a final concentration of $100 \mu \mathrm{g} / \mathrm{ml}$ in PBS (pH 7.4). The 96-well plates were coated with $5 \mu \mathrm{g} / \mathrm{ml} \mathrm{ECM}$ proteins at $4{ }^{\circ} \mathrm{C}$ overnight. A375 cells were pretreated with hirudin $(5,10$, or $20 \mathrm{mg} / \mathrm{ml})$ or LMWH $(200 \mathrm{IU} / \mathrm{ml})$ in serum-free medium $(\mathrm{SFM})$ at $37^{\circ} \mathrm{C}$ in a $5 \%$ $\mathrm{CO}_{2}$ atmosphere for $1 \mathrm{~h}$. After treatment, $5 \times 10^{4}$ cells per well were added to the plates to adhere to the matrix in SFM at $37^{\circ} \mathrm{C}$ in a $5 \% \mathrm{CO}_{2}$ atmosphere for $1 \mathrm{~h}$. The cells that did not adhere to the matrix were discarded and the bound cells were fixed with $50 \mu \mathrm{l}$ of $50 \%$ trichloroacetic acid at $2{ }^{\circ} \mathrm{C}$ for $1 \mathrm{~h}$. The wells were rinsed 5 times with tap water to remove solute and allowed to dry thoroughly. The bound cells were then stained with $200 \mu \mathrm{l} /$ well of Sulforhodamine B (Sigma, $0.4 \%$ in $1 \%$ acetic acid) for 30 min and rinsed 4 times in $1 \%$ acetic acid. After drying, a volume of $200 \mu \mathrm{l}$ of $10 \mathrm{~mm}$ unbuffered Tris base (pH 10.5, Tris (hydroxymethyl)-methylamine) per well was added followed by mixing, and the absorbance value of samplez was measured on a microplate reader at $540 \mathrm{~nm}$ with a reference at $690 \mathrm{~nm}^{30 \text { ) }}$

Cell Invasion and Migration Assay Cell invasion assays were carried out in a 96-well ChemoTx ${ }^{\circledR}$ microplate (polycarbonate filter with $8-\mu \mathrm{m}$ pore size) (Neuro Probe, Inc., Gaithersburg, MD, U.S.A.). The upper surface of the filter was coated with ECM gel $(50.0 \mu \mathrm{g} / \mathrm{ml})$ at $4{ }^{\circ} \mathrm{C}$ overnight. A375 cells were pretreated with hirudin $(5.0,10.0,20.0$ $\mathrm{mg} / \mathrm{ml})$ or LMWH $(200 \mathrm{IU} / \mathrm{ml})$ for $30 \mathrm{~min}$. Cells were then suspended in DMEM supplemented with 5\% FBS and added to the upper chamber $\left(5 \times 10^{4}\right.$ cells/well $)$. The lower chamber was filled with $30 \mu \mathrm{l}$ DMEM supplemented with $10 \%$ FBS. After incubation at $37^{\circ} \mathrm{C}$ in a $5 \% \mathrm{CO}_{2}$ atmosphere for $24 \mathrm{~h}$, cells on the upper surface of the filter were removed with a cotton swab, and the invaded cells on the lower surface were fixed in methanol for $5 \mathrm{~min}$ and stained with $1 \%$ toluidineblue (Sigma, St. Louis, MO, U.S.A.) for $5 \mathrm{~min}$. The number of invaded cells was counted under a microscope $(\times 200)$.

In vitro migration assays were performed under the same conditions as the invasion assays but ECM gel was replaced with PBS (pH 7.4).

Measurement of Coagulation Parameters in Mice Female BALB/c mice (Vital Laboratory Animal Center, Beijing, China), $22-25 \mathrm{~g}$, were used in the animal experiments. All experimental protocols were carried out in accordance with the Guidelines for Animal Experiments, ${ }^{31)}$ and all care and handling of animals were performed with the approval of Institutional Authority for Laboratory Animal Care of Peking University.

The anticoagulant effect of hirudin was measured by activated partial thromboplastin time (aPTT) and thrombin time (TT). One day and $1 \mathrm{~h}$ before blood taking, hirudin (5.0, $10.0,20.0 \mathrm{mg} / \mathrm{kg})$ or LMWH $(200 \mathrm{IU} / \mathrm{kg})$ was administered intraperitoneally to the mice. Mice were anaesthetized by intraperitoneal administration of pentobarbital sodium and blood was taken from the orbit venous plexus. Fresh blood was anticoagulated with $3.8 \%$ trisodium citrate solution (citrate: blood ratio $=1: 10, \mathrm{v} / \mathrm{v})$. The samples were centrifuged at $8000 \mathrm{rpm}$ for $10 \mathrm{~min}$ and the coagulation parameters were determined by aPTT and TT kits (Shanghai Sun Biotech Co., Ltd., Shanghai, China) by following the manufacturer's kit guides. For TT assay, if the coagulation time was $>120 \mathrm{~s}$ or the samples did not coagulate at all, TT values were recorded as $120 \mathrm{~s}$ according to a standard criterion. ${ }^{32)}$
Inhibition of Tumor Growth in Mice Single-cell suspensions were prepared from $0.25 \%$ trypsin-treated monolayer of B16 melanoma cultures, washed, and diluted in physiological saline. A volume of $200 \mu \mathrm{l}$ cell suspensions (approximately $8 \times 10^{6}$ tumor cells per animal) was injected subcutaneously into the armpit of female $\mathrm{BALB} / \mathrm{c}$ mice. Hirudin $(5.0,10.0,20.0 \mathrm{mg} / \mathrm{kg})$ or LMWH $(200 \mathrm{IU} / \mathrm{kg})$ was administered intraperitoneally once daily for $5 \mathrm{~d}$ consecutively, namely, on 1 day before, and $0,1,2$, and $3 \mathrm{~d}$ after tumor cell inoculation. Stealthy liposomal vinblastine (1 $\mathrm{mg} / \mathrm{kg}$ ) was given to the mice via tail vein on 8,10 , and $12 \mathrm{~d}$ after tumor cell inoculation. A volume of $100 \mu \mathrm{l}$ physiological saline was given as control at each administration timepoint for hirudin or stealthy liposomal vinblastine. The mice were monitored daily for tumor volume and sacrificed on the 14th day. Tumor volume was calculated using the formula: $V=\pi \times\left(\right.$ length $\times$ width $\left.^{2}\right) / 6$.

Inhibition of Metastasis in Mice Tumor cells were prepared as above. Briefly, a volume of $200 \mu \mathrm{l}$ cell suspensions (approximately $8 \times 10^{6}$ tumor cells per animal) was injected intravenously into the tail vein of female $\mathrm{BALB} / \mathrm{c}$ mice. Hirudin $(5.0,10.0,20.0 \mathrm{mg} / \mathrm{kg})$ or LMWH $(200 \mathrm{IU} / \mathrm{kg})$ was administered intraperitoneally once daily for $5 \mathrm{~d}$ consecutively; namely, on $1 \mathrm{~d}$ before, and $0,1,2$, and $3 \mathrm{~d}$ after tumor cell injection. Stealthy liposomal vinblastine $(1 \mathrm{mg} / \mathrm{kg})$ was given to mice via tail vein on 15,17 , and $19 \mathrm{~d}$ after tumor cell injection. A volume of $100 \mu$ physiological saline was given as control at each administration time-point for hirudin or stealthy liposomal vinblastine. The mice were sacrificed on the 21 st day. Lungs were removed and fixed in $4 \%$ formalin. Surface tumor colonies were counted under microscope $(\times 200)$.

Statistics Data are presented as the mean \pm standard deviation (S.D.). One-way analysis of variance (ANOVA) was used to determine significance among groups, after which post hoc tests with the Bonferroni correction were used for comparison between individual groups. A value of $p<0.05$ was considered significant.

\section{RESULTS}

Characterization of Stealthy Liposomal Vinblastine In vitro characterization of vinblastine-loaded stealthy liposomes is shown in Table 1. The average particle size of stealthy liposomal vinblastine was $117.3 \pm 4.3 \mathrm{~nm}$, polydispersity index $0.31 \pm 0.04$, and zeta potential $-12.3 \pm 1.5 \mathrm{mV}$. The encapsulation efficiency of stealthy liposomal vinblastine was $95 \%$. Liposomes showed slight vinblastine leakage in PBS ( $\mathrm{pH} \mathrm{7.4)} \mathrm{at} \mathrm{early} 12 \mathrm{~h}$ in the static state but the liposomes were stable thereafter, and in 50\% FBS the leakage was about $40 \%$ at $48 \mathrm{~h}$, as shown in Fig. 1.

Tumor Cell Proliferation in Vitro Results from MTT

Table 1. In vitro Characterization of Stealthy Liposomal Vinblastine

\begin{tabular}{lc}
\hline \hline Parameter & Value \\
\hline Average particle size & $117.3 \pm 4.3 \mathrm{~nm}$ \\
Polydispersity index (PDI) & $0.31 \pm 0.04$ \\
Zeta potential & $-12.3 \pm 1.5 \mathrm{mV}$ \\
Encapsulation efficiency & $95.1 \pm 2.8 \%$
\end{tabular}

Each value represents the mean \pm standard deviation and repeated in triplicate. 


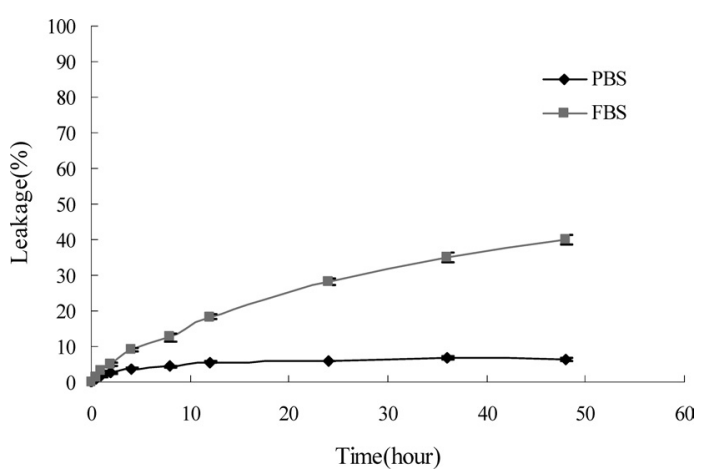

Fig. 1. Leakage of Vinblastine from Stealthy Liposomes in PBS ( $\mathrm{pH}$ 7.4) or $50 \%$ Fetal Bovine Serum (FBS) in PBS

Data are presented as mean \pm standard deviation (S.D.) and repeated in triplicate.

assay revealed that hirudin $(5.0,10.0,20.0 \mathrm{mg} / \mathrm{ml})$ had no effect on the growth of A375 melanoma cells, as shown in Fig. 2a. Vinblastine or stealthy liposomal vinblastine alone was effective in inhibiting A375 melanoma cells growth, in a dose-dependent manner, as exhibited in Figs. 2b and c. Free vinblastine showed more potent effect than stealthy liposomal vinblastine in vitro. After co-treating vinblastine with hirudin, the antiproliferative effect was not enhanced obviously, as indicated in Fig. 2d. In addition, LMWH did not show any cytotoxic effect on the growth of the tumor cells (data not shown).

Interaction of Tumor Cells with ECM Proteins in Vitro For observing the effect of hirudin $(5.0,10.0,20.0 \mathrm{mg} / \mathrm{ml})$ or LMWH $(200 \mathrm{IU} / \mathrm{ml})$ on tumor cell adhesion to ECM proteins, melanoma cells were incubated on plates coated with ECM proteins: fibrinogen, fibronectin, ECM gel, and collagen I for $60 \mathrm{~min}$, and the percentage of adherent cells was determined. The results showed that hirudin did not affect adhesion of A375 melanoma cells to the matrix protein, as shown in Fig. 3a. Similar results were observed in experiments in which LMWH was applied (data not shown).

Migration and invasion of A375 melanoma cells were also examined after applying hirudin $(5.0,10.0,20.0 \mathrm{mg} / \mathrm{ml})$ and LMWH $(200 \mathrm{IU} / \mathrm{ml})$. The results showed that pre-treatment with hirudin did not affect cell migration using PBS medium, and invasion using ECM gel. However, LMWH significantly inhibited cell migration and matrix invasion of A375 melanoma cells, as shown in Figs. $3 \mathrm{~b}$ and c.

Effect of Hirudin on Mouse Hemostasis The blood coagulation parameters, aPTT and TT, were measured after the mice were treated with hirudin $(5.0,10.0,20.0 \mathrm{mg} / \mathrm{kg})$ or LMWH (200 IU/kg). Following hirudin administration, aPTT values were obviously extended at a medium dose (10.0 $\mathrm{mg} / \mathrm{kg})$ and a high dose $(20.0 \mathrm{mg} / \mathrm{kg})$. TT values were evidently increased at all dose levels of hirudin, showing that the blood samples were not coagulated at all in $120 \mathrm{~s}$. In contrast, aPTT values seemed not to be altered following administration of LMWH while TT values were significantly increased, as shown in Fig. 4.

Effect on Tumor Cell Proliferation in Vivo After murine B16 melanoma cells were inoculated in mice, tumor masses appeared after approximately $3-5 \mathrm{~d}$. After hirudin $(5.0,10.0,20.0 \mathrm{mg} / \mathrm{kg})$, or LMWH $(200 \mathrm{IU} / \mathrm{kg})$ were given for 5 consecutive days, the tumor sizes on the 7 th day were smaller (at a medium dose of hirudin) or significantly smaller a

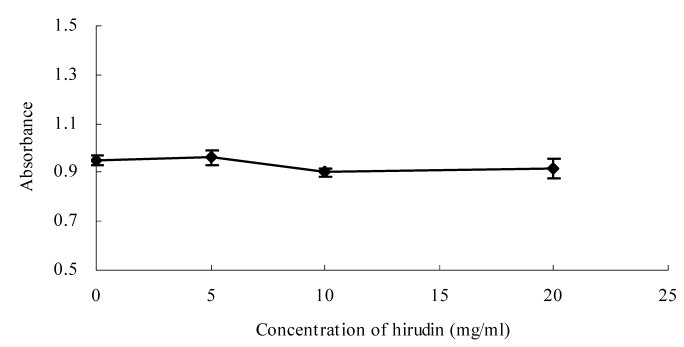

b

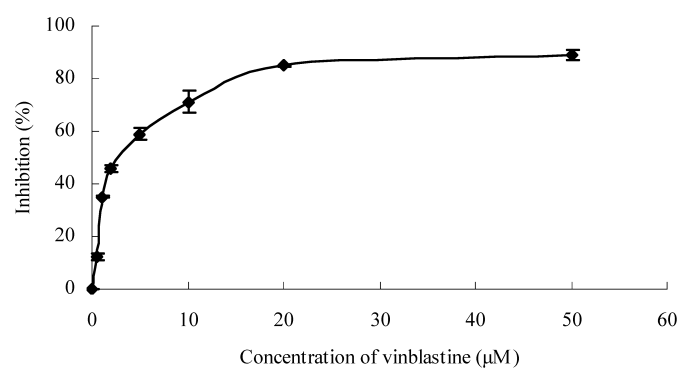

c

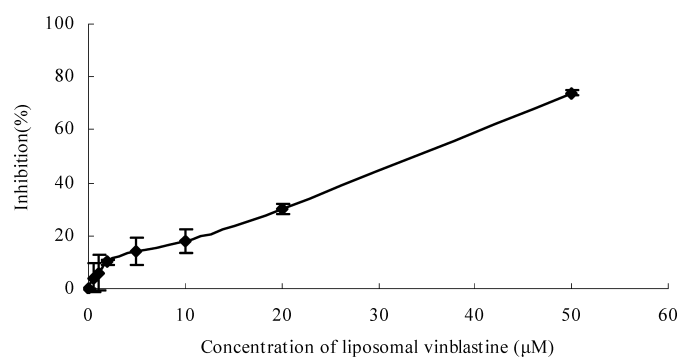

d

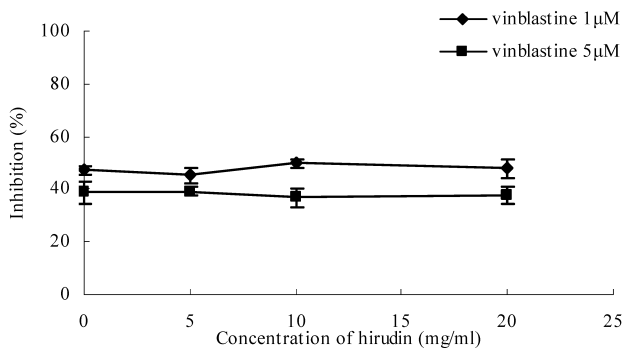

Fig. 2. Effects of Hirudin (a), Vinblastine (b), Stealthy Liposomal Vinblastine (c), and Vinblastine Co-treated with Hirudin (d) on Growth of A375 Melanoma Cells

Cells were incubated with the indicated concentrations of drugs for $48 \mathrm{~h}$. Data are presented as mean \pm standard deviation (S.D.) from 6 wells of an experiment, and repeated in triplicate.

(at a higher dose of hirudin) as compared with in mice given physiological saline as control. Unlike as reported previously, ${ }^{1)}$ LMWH did not show more effect on delay of tumor growth as compared with control (physiological saline), as shown in Fig. 5a. Following administration of stealthy liposomal vinblastine $(1 \mathrm{mg} / \mathrm{kg})$ on the $8 \mathrm{th}, 10 \mathrm{th}$, and 12th day, tumor growth trend was significantly lowered at various time-points. Among groups, the tumor sizes of the mice after administrations of hirudin at a high dose (20.0 


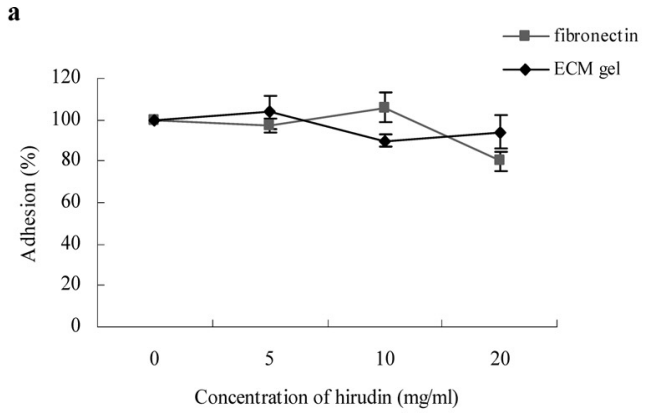

b

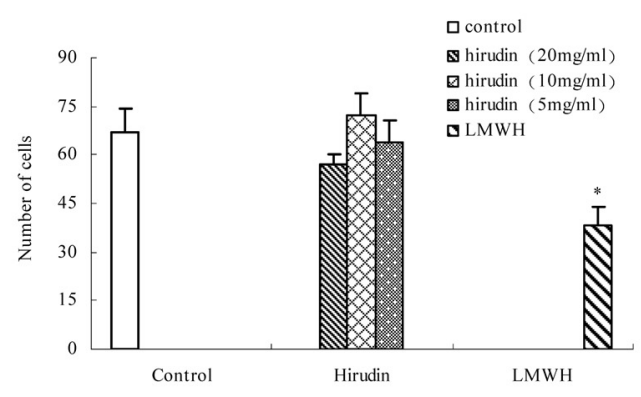

c

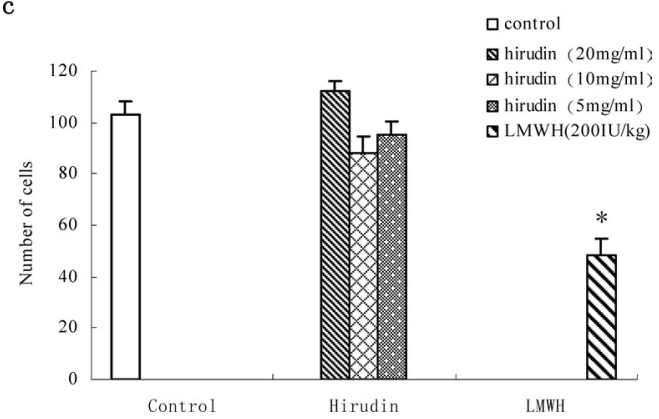

Fig. 3. Effect of Hirudin and Low-molecular Weight Heparin (LMWH) on Matrix Adhesion, Migration, and Extracellular Matrix (ECM) Gel Invasion of A375 Melanoma Cells in Vitro

(a) The value in y-ordinate was ratio of the attached cells over cells alone as control, and cells were incubated with ECM gel or fibronectin for $60 \mathrm{~min}(n=6)$; (b) and (c) A375 cells were incubated with PBS (pH 7.4) for migration, and with ECM gel for invasion observation at $37^{\circ} \mathrm{C}$ for $24 \mathrm{~h}(n=6) . * p<0.05$ versus control.

$\mathrm{mg} / \mathrm{kg})$ or a medium dose $(10.0 \mathrm{mg} / \mathrm{kg})$ followed by treatment with stealthy liposomal vinblastine were the smallest as compared with those in other groups, as shown in Fig. $5 b$.

Effect on Lung Metastasis of Tumor Cells B16 melanoma cells were injected i.v. into mice treated with hirudin $(5.0,10.0,20.0 \mathrm{mg} / \mathrm{kg})$ or LMWH $(200 \mathrm{IU} / \mathrm{kg})$ followed by administration of stealthy liposomal vinblastine (1 $\mathrm{mg} / \mathrm{kg}$ ) on the 15th, 17th, 19th day. At termination (on the 21 st day), lung colonies in mice treated with hirudins or LMWH were all less than that of control, showing that lung metastasis formation was inhibited by hirudin and LMWH. Furthermore, the lung colonies of mice treated with hirudin or LMWH followed by administration of stealthy liposomal vinblastine were less than those of mice treated with stealthy liposomal vinblastine, hirudin, or LMWH alone, as shown in Fig. 6.

Figure 7 shows a photograph of lungs of mice treated with physiological saline, hirudin $(20.0 \mathrm{mg} / \mathrm{kg})$, hirudin $(20.0$

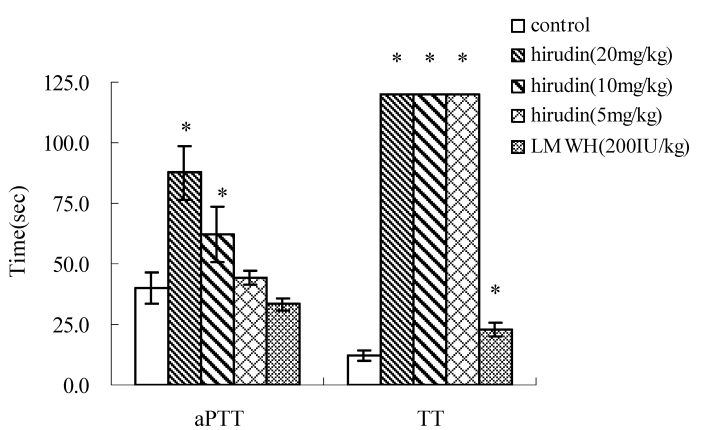

Fig. 4. Effect of Hirudin and Low-molecular Weight Heparin (LMWH) on Activated Partial Thromboplastin Time (aPTT) and Thrombin Time (TT) in Mice $(n=6)$

For TT assay, if the coagulation time was $>120 \mathrm{~s}$ or the samples did not coagulate at all, TT values were recorded as $120 \mathrm{~s}$ according to a standard criterion. $* p<0.05$ versus control.
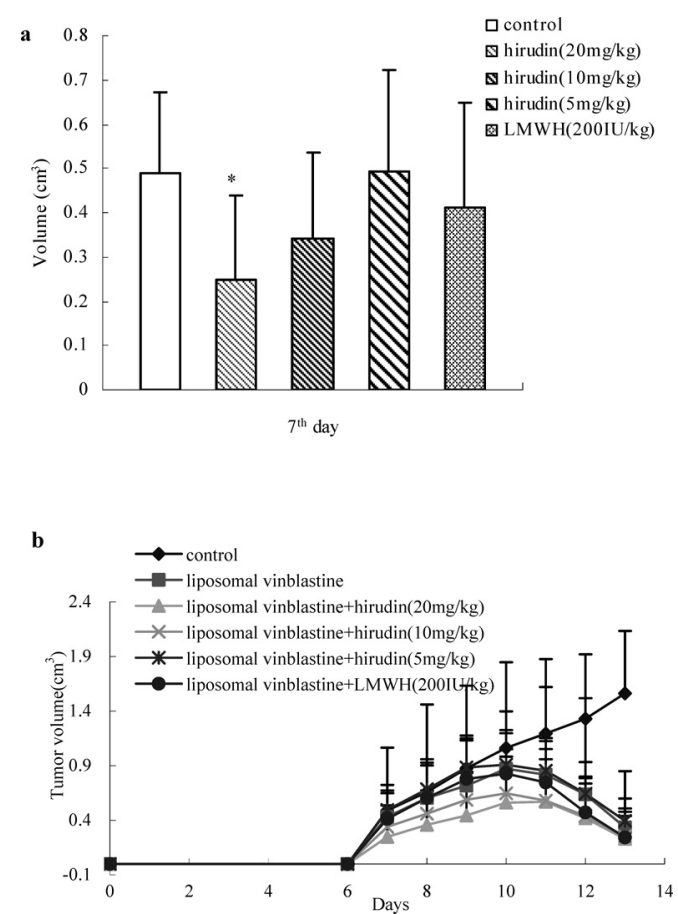

Fig. 5. Effect of Hirudin and Liposomal Vinblastine on Growth of Murine B16 Melanoma Cells Transplanted in BALB/c Mice $\left(8 \times 10^{6}\right.$ Tumor Cells per Animal)

Hirudin or low-molecular weight heparin (LMWH) was administered intraperitoneally daily on $1 \mathrm{~d}$ before and $0,1,2$ and $3 \mathrm{~d}$ after tumor cell inoculation. Stealthy liposomal vinblastine $(1 \mathrm{mg} / \mathrm{kg})$ or physiological saline as control was given to mice via tail vein on the 8 th, 10 th, and 12 th day after inoculation of tumor cells. Data are presented as mean \pm standard deviation $(n=5-6)$. (a) Mean volume of mice on the 7 th day following daily daministration of hirudin or LMWH for $5 \mathrm{~d}$ (b) Mean tumor volume of mice measured on various days.

$\mathrm{mg} / \mathrm{kg}$ ) plus stealthy liposomal vinblastine, stealthy liposomal vinblastine $(1 \mathrm{mg} / \mathrm{kg})$, and LMWH $(200 \mathrm{IU} / \mathrm{kg})$. As can be seen, the rank order for anti-metastatic effect in vivo was as follows: hirudin $(20.0 \mathrm{mg} / \mathrm{kg})$ plus stealthy liposomal vinblastine $(1 \mathrm{mg} / \mathrm{kg})>$ hirudin $(20.0 \mathrm{mg} / \mathrm{kg})>$ stealthy liposomal vinblastine $(1 \mathrm{mg} / \mathrm{kg})>\mathrm{LMWH} \quad(200 \mathrm{IU} / \mathrm{kg})>$ physiological saline (the control).

\section{DISCUSSION}

In this work we first studied the effect of stealthy liposomal vinblastine co-treated with anticoagulant recombinant 


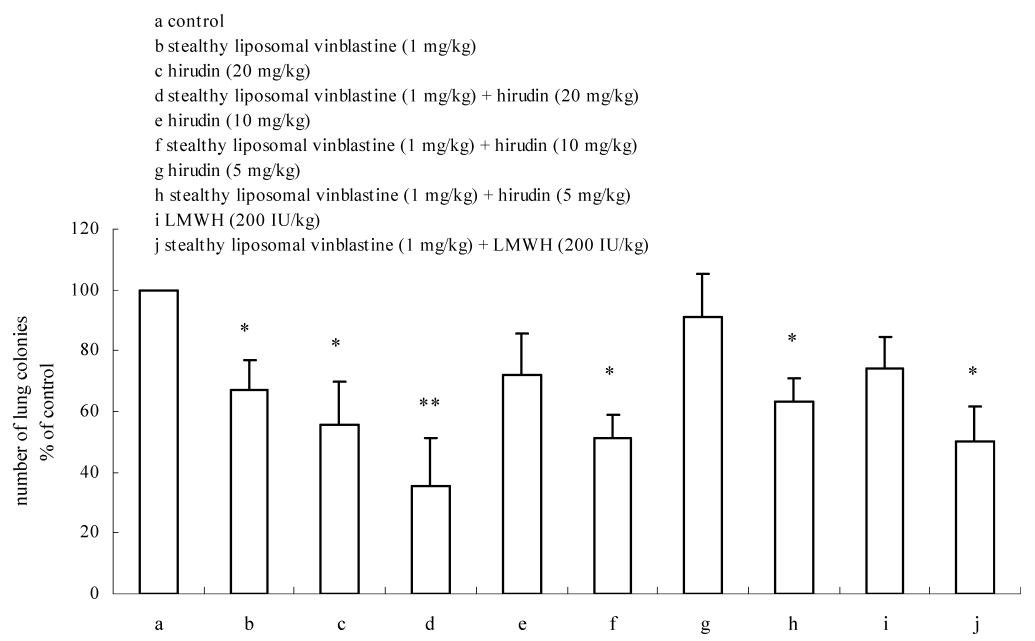

Fig. 6. Effect of Hirudin and Liposomal Vinblastine on Lung Metastasis of Murine B16 Melanoma Cells

Approximately $8 \times 10^{6}$ tumor cells per animal were injected intravenously into the tail vein of the mice. Hirudin or low-molecular weight heparin (LMWH) was administered intraperitoneally daily on $1 \mathrm{~d}$ before and $0,1,2$ and $3 \mathrm{~d}$ after tumor cell injection. Stealthy liposomal vinblastine $(1 \mathrm{mg} / \mathrm{kg}$ ) or physiological saline as a control was given to mice via tail vein on the 15 th, 17 th, and 19 th days after injection of tumor cells. The mice were sacrificed on the 21 st day. Lungs were removed and fixed in $4 \%$ formalin. The surface tumor colonies of lungs were counted under microscope $(\times 200)$. Data are presented as mean \pm standard deviation $(n=4-6)$. a, control; b, liposomal vinblastine $(1 \mathrm{mg} / \mathrm{kg}) ; \mathrm{c}$, hirudin $(20$ $\mathrm{mg} / \mathrm{kg}) ; \mathrm{d}$, liposomal vinblastine (1 mg/kg) plus hirudin $(20 \mathrm{mg} / \mathrm{kg}) ; \mathrm{e}$, hirudin $(10 \mathrm{mg} / \mathrm{kg}) ; \mathrm{f}$, liposomal vinblastine $(1 \mathrm{mg} / \mathrm{kg}) \mathrm{plus} \mathrm{hirudin}(10 \mathrm{mg} / \mathrm{kg}) ; \mathrm{g}$, hirudin (5 mg/kg); h, liposomal vinblastine $(1 \mathrm{mg} / \mathrm{kg})$ plus hirudin $(5 \mathrm{mg} / \mathrm{kg}) . * p<0.05$ versus control. $* * p<0.05$ versus liposomal vinblastine.
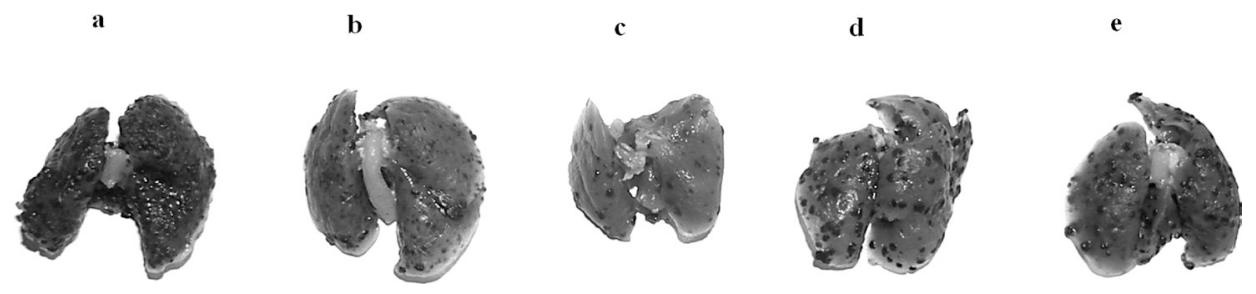

Fig. 7. Surface Tumor Colonies of B16 Melanoma Lung Metastasis

(a) Tumor colonies treated with physiological saline as blank control; (b) tumor colonies treated with hirudin (20 mg/kg); (c) tumor colonies co-treated liposomal vinblastine $(1 \mathrm{mg} / \mathrm{kg})$ with hirudin $(20 \mathrm{mg} / \mathrm{kg})$; (d) tumor colonies treated with liposomal vinblastine $(1 \mathrm{mg} / \mathrm{kg})$ alone; (e) tumor colonies treated with LMWH (200 IU/kg) as a positive control.

hirudin on the in vitro and in vivo invasion, metastasis, and growth of melanoma. The results demonstrate that stealthy liposomal vinblastine plus hirudin are more potent than stealthy liposomal vinblastine alone in the inhibition of tumor growth and metastasis in vivo.

To understand the effect of hirudin, vinblastine, or stealthy liposomal vinblastine on growth of tumor cells, experiments of inhibition of tumor cell growth in vitro and in vivo were performed. The data indicate that stealthy liposomal vinblastine has obvious anticancer effect on human A375 melanoma cell line in vitro and murine B16 melanoma cell line in vivo. In contrast, hirudin had no influence on growth of A375 cell in vitro, suggesting that its effect on the growth of tumor cells in vivo may not be relevant to its cytotoxicity. The results from anti-tumor effect of stealthy liposomal vinblastine and hirudin in vivo show that the tumor volumes of the groups treated with hirudin (high dosage and middle dosage) on the 7 th day are smaller or slightly smaller than that of the control, indicating that hirudin is capable of inhibiting tumor implantation and growth of murine B16 melanoma cells in BALB/c mice. The likely reasons may be attributed to the effect of hirudin on the activity of thrombin in vivo. Thrombin could induce the adhesion of tumor cells to ECM proteins, and the genesis of vascular endothelial growth factor (VEGF) by tumor cells or normal cells. These functions of thrombin mainly depend on the receptor of thrombin on cells surface, protease-activated receptor (PAR). B16 melanoma cells express PAR-1 on the cell surface, and PAR-1 can be activated when combining with thrombin to induce a series of physiological reactions, and hence affect the growth of tumor cells in vivo. ${ }^{33,34)}$ After administration of hirudin, a highly specific thrombin inhibitor, the activity of thrombin is inhibited thus leading to restrained growth of tumor cells.

To define the effect of hirudin and stealthy liposomal vinblastine on metastasis of tumor cells, experimental lung metastasis in vivo was studied. The results indicate that hirudin has anti-metastasis effect on experimental metastasis of murine B16 melanoma cells. Most likely, the mechanism could be due to the observation that thrombin induces adhesion and aggregation (clot formation) of tumor cells to platelets, and helps tumor cells escapethe monitoring of host immune system. Clot formation may act as a role in the metastatic process through a variety of mechanisms including protecting cancer cells from natural killer cells or from the physical stress of blood flow, facilitating ${ }^{35)}$ tumor cell attachment to vessel walls. Such an attachment may result in the production of proteolytic enzymes released by tumor cells, thus enhancing the extravasation of tumor cells, or angiogenesis. After administration, hirudin could decrease the number of tumor cells by suppressing the thrombin activity, hence showing an anti-metastatic effect.

Measurements of the coagulation parameters, aPTT and TT, were performed for observing the state of thrombin activity. The present study indicates that thrombin activity of 
mice is suppressed after administration of hirudin, further suggesting that the anti-metastatic or anti-tumor growth effect of hirudin is through its inhibiting effect on thrombin activity.

In the in vitro experiments of tumor cell adhesion to ECM proteins, migration and invasion through ECM gel, the results showed that hirudin has no impact on tumor cells in vitro. These phenomena are not comparable to those of another anticoagulant, LMWH, which exhibited significant influences on the in vitro migration and invasion. The likely reason might be because there are no relevant proteins or molecules on the tumor cell surface that could react with hirudin. On the contrary, in vivo hirudin significantly influenced metastasis of tumor cells, suggesting that the effect of hirudin on tumor cells in vivo was not associated with the interaction between hirudin and tumor cells but relevant to thrombin activity, as described below. A previous report indicates that the P-selectin-mediated antimetastatic effect of heparin could be due to the interaction between heparin and glycosaminoglycan chains of the tumor cell surface heparan sulfate-like proteoglycans (HSPGs). ${ }^{36)}$

In considering the relations between development of tumor cells and thrombin, thrombin can be generated by tumor cells. Tumor cells are unique because they have constitutively active tissue factor on the surface. ${ }^{37,38)}$ The tissue factor could induce thrombin generation, which in turn could stimulate tumor cell growth, adhesion, and invasion. In the presence of hirudin, thrombin activity could be inhibited hence resulting in a decreased trend in ability of tumor cell adhesion, growth, invasion, and metastasis. It has been reported that tissue factor expression correlates with hematogenous metastases in melanoma cells ${ }^{39-41)}$ and invasive breast carcinomas. ${ }^{42)}$ Nevertheless, a number of blood components may have dual effects on the growth or metastasis of melanomas: inhibiting or promoting effects. The inhibitory effect of hirudin on melanomas through acting on other blood components merits further investigation.

In conclusion, administration of recombinant hirudin followed by giving stealthy liposomal vinblastine may be beneficial for inhibiting the growth and metastasis of melanoma in vivo. The likely mechanism could be associated with inhibition of thrombin after administration of hirudin.

Acknowledgements This paper was supported by Grant 985, Project of Ministry of Education of China (Peking University, Phase II), and supported in part by Grant of National Science Foundation of China (No. 30430760).

\section{REFERENCES}

1) Bereczky B., Gilly R., Raso E., Vago A., Timar J., Tovari J., Clin. Exp. Metastasis, 22, 69-76 (2005).

2) Hu L., Lee M., Campbell W., Perez-Soler R., Karpatkin S., Blood, 104, 2746-2751 (2004).

3) Rickles F. R., Edwards R. L., Blood, 62, 14-31 (1983).

4) Rickles F. R., Edwards R. L., Barb C., Cronlund M., Cancer, 51, 301-307 (1983).

5) Sun N., McAfee W. M., Hum G. J., Weiner J. M., Am. J. Clin. Pathol., 71, 10-16 (1979).

6) Yoda Y., Abe T., Thromb. Haemost., 46, 706-709 (1981).

7) Nierodzik M. L., Plotkin A., Kajumo F., Karpatkin S., J. Clin. Invest., 87, 229-236 (1991)
8) Nierodzik M. L., Kajumo F., Karpatkin S., Cancer Res., 52, 3267 3272 (1992).

9) Wojtukiewicz M. Z., Tang D. G., Nelson K. K., Walz D. A., Diglio C. A., Honn K. V., Thromb. Res., 68, 233-245 (1992).

10) Klepfish A., Greco M. A., Karpatkin S., Int. J. Cancer, 53, 978-982 (1993).

11) Zain J., Huang Y. Q., Feng X., Nierodzik M. L., Li J. J., Karpatkin S., Blood, 95, 3133-3138 (2000).

12) Nierodzik M. L., Chen K., Takeshita K., Li J. J., Huang Y. Q., Feng X. S., D’Andrea M. R., Andrade-Gordon P., Karpatkin S., Blood, 92, 3694-3700 (1998).

13) Wojtukiewicz M. Z., Tang D. G., Nelson K. K., Walz D. A., Diglio C. A., Honn K. V., Int. J. Cancer, 54, 793 -806 (1993).

14) Ruf W., Mueller B. M., Semin. Thromb. Hemost., 32, 61-68 (2006).

15) Heras M., Chesebro J. H., Webster M. W., Mruk J. S., Grill D. E., Penny W. J., Bowie E. J., Badimon L., Fuster V., Circulation, 82, 1476 - 1484 (1990).

16) Klocking H. P., Schulze-Riewald H., Markwardt F., Folia Haematol. Int. Mag., Klin. Morphol. Blutforsch, 115, 106-109 (1988).

17) Agnelli G., Pascucci C., Cosmi B., Nenci G. G., Thromb Haemost., 63, 204-207 (1990).

18) Retik A. B., Arons M. S., Ketcham A. S., Mantel N., J. Surg. Res., 11, 49-53 (1962)

19) Hagmar B., Pathol. Eur., 4, 283-292 (1969).

20) Hagmar B., Acta Pathol. Microbiol. Scand. A, 78, 131-142 (1970).

21) Honn K. V., Tang D. G., Crissman J. D., Cancer Metastasis Rev., 11, 325-351 (1992).

22) Makabe T., Saiki I., Murata J., Ohdate Y., Kawase Y., Taguchi Y., Shimojo T., Kimizuka F., Kato I., Azuma I., J. Biol. Chem., 265, 1427014276 (1990).

23) Antachopoulos C. T., Iliopoulos D. C., Gagos S., Agapitos M. V., Karayannacos P. E., Roboli S. K., Skalkeas G. D., Anticancer Res., 15, $1411-1416$ (1995).

24) Tyrrell D. J., Horne A. P., Holme K. R., Preuss J. M., Page C. P., $A d v$. Pharmacol., 46, 151-208 (1999).

25) Lu W. L., Qi X. R., Zhang Q., Li R. Y., Wang G. L., Zhang R. J., Wei S. L., J. Pharmacol. Sci., 95, 381-389 (2004).

26) Yuan F., Dellian M., Fukumura D., Leunig M., Berk D. A., Torchilin V. P., Jain R. K., Cancer Res., 55, 3752-3756 (1995).

27) Harrington K. J., Mohammadtaghi S., Uster P. S., Glass D., Peters A. M., Vile R. G., Stewart J. S. W., Clin. Cancer Res., 7, 243-254 (2001).

28) Li X., Lu W. L., Liang G. W., Ruan G. R., Hong H. Y., Long C., Zhang Y. T., Liu Y., Wang J. C., Zhang X., Zhang Q., Eur. J. Clin. Invest., 36, 409-418 (2006).

29) Mosmann T., J. Immunol. Methods, 65, 55-63 (1983).

30) Martin M., Clynes M., Cytotechnology, 11, 49-58 (1993).

31) United Kingdom Co-ordinating Committee on Cancer Research (UKCCCR). Guidelines for the Welfare of Animals in Experimental Neoplasia (Second Edition). Br. J. Cancer, 77, 1-10 (1998).

32) Sirrdge M. S., Shannon R., "Laboratory Evaluation of Hemostasis \& Thrombosis," 3rd ed., Lea \& Febiger, Philadelphia, 1983.

33) Even-Ram S., Uziely B., Cohen P., Grisaru-Granovsky S., Maoz M., Ginzburg Y., Reich R., Vlodavsky I., Bar-Shavit R., Nat. Med., 4, 909-914 (1998).

34) Shi X., Gangadharan B., Brass L. F., Ruf W., Mueller B. M., Mol. Cancer Res., 2, 395-402 (2004).

35) Fukai F., Takahashi H., Habu Y., Kubushiro N., Katayama T., Biochem. Biophys. Res. Commun., 220, 394-398 (1996).

36) Ma Y. Q., Geng J. G., J. Immunol., 165, 558-565 (2000).

37) Pearlstein E., Ambrogio C., Gasic G., Karpatkin S., Cancer Res., 41, 4535-4539 (1981).

38) Cavanaugh P. G., Sloane B. F., Honn K. V., Haemostasis, 18, 37-46 (1988).

39) Fischer E. G., Ruf W., Mueller B. M., Cancer Res., 55, 1629-1632 (1995).

40) Mueller B. M., Reisfeld R. A., Edgington T. S., Ruf W., Proc. Natl. Acad. Sci. U.S.A., 89, 11832-11836 (1992).

41) Bromberg M. E., Konigsberg W. H., Madison J. F., Pawashe A., Garen A., Proc. Natl. Acad. Sci. U.S.A., 92, 8205-8209 (1995).

42) Contrino J., Hair G., Kreutzer D. L., Rickles F. R., Nat. Med., 2, 209 215 (1996). 